\title{
PERBANDINGAN JENIS MEDIA TANAM TANAH ENTISOL YANG TERPAPAR SATU KALI DAN DUA KALI OLEH LIMBAH CAIR NANAS TERHADAP PERTUMBUHAN SELEDRI (Apium graveolens L.) SEBAGAI SUMBER BELAJAR BIOLOGI
}

\author{
Irma Yunita Sari \\ Kartika Sari \\ Pendidikan Biologi FKIP Universitas Muhammadiyah Metro. \\ E-mail: irmajosy@yahoo.com
}

\begin{abstract}
This research to know effect of Pineapple Liquid Compost $(P L C)$ in long term the growth of celery. This research conducted at the village in Yosodadi 21 Polos, East Metro, Metro City since 7 December until 28 February 2015. This research is experimental research, the design used the Complete Random Design (CRD). This research used entisol soil that was exposed by PLC once and entisol soil that was exposed by PLC twice. The treatment was done to them both by giving PLC about 200ml in a time per three days. The data analysis was done by using normality test (liliefors), homogeneity test (barlett) and $T_{\text {tes. }}$ It shows that there is no negative effect of fertilizer use PLC in the long term against the growth of celery in entisol soil that was exposed by PLC once and entisol soil that was exposed by PLC twice.
\end{abstract}

Kata Kunci: pupuk limbah cair nanas (LCN), tanah entisol, pertumbuhan seledri (Apium graveolens L.), lembar kegiatan siswa

Dewasa ini banyak pupuk yang digunakan oleh petani guna memenuhi unsur kebutuhan tanaman. Pupuk itu sendiri dapat berupa pupuk organik maupun pupuk anorganik. Kedua macam pupuk tersebut biasanya berbentuk cair maupun padat. Salah seorang petani yang menggunakan pupuk cair yaitu petani kopi yang bertempat tinggal di Desa Bangunrejo Lampung Tengah. Berdasarkan hasil wawancara, beliau menggunakan pupuk cair untuk tanaman kopinya. Setelah menggunakan pupuk cair dalam jangka panjang ternyata menimbulkan dampak negatif. Produksi tanaman kopi semakin lama semakin menurun. Hal tersebut tentunya mencemaskan para petani akan penggunaan pupuk cair dalam jangka panjang.

Pupuk organik cair biasanya berasal dari limbah. Seperti halnya pupuk organik cair dari limbah industri nanas. Limbah cair nanas telah dijadikan sebagai pupuk organik Limbah Cair Nanas (LCN). Limbah Cair Nanas (LCN) terdapat kandungan unsur $\mathrm{P}, \mathrm{K}, \mathrm{C}, \mathrm{Ca}, \mathrm{Mg}, \mathrm{Na}, \mathrm{Fe}, \mathrm{Zn}, \mathrm{Mn}$, $\mathrm{S}, \mathrm{NO}_{3}, \mathrm{NH}_{4}$, dan $\mathrm{C} / \mathrm{N}$ (Julius dalam Sutanto, 2010:76). Kandungan tersebut berpotensi sebagai pemenuhan unsur hara bagi tanaman. Proses pengolahan Limbah Cair Nanas (LCN) menjadi 
pupuk cair ini dilakukan dengan menggunakan bioremediasi. Bioremediasi sendiri merupakan "proses mengubah senyawa pencemar organik yang berbahaya menjadi senyawa yang lebih aman dengan memanfaatkan organisme" (Sutanto, 2010:9). Setelah proses pengolahan yang demikian, maka pupuk limbah cair nanas diharapkan dapat dijadikan pupuk cair yang berpotensi ramah lingkungan, aman dan efektif.

Berdasarkan hasil penelitian oleh Setyawati (2014) bahwa penggunaan pupuk limbah cair nanas ini mampu meningkatkan produksi pada tanaman terung. Berkenaan dengan hal tersebut, pupuk limbah cair nanas ini diharapkan dapat diaplikasikan pada berbagai macam tanaman yang lainnya seperti tanaman seledri. Kandungan unsur yang terdapat pada pupuk limbah cair nanas dapat menunjang dan memenuhi kebutuhan unsur hara pada tanaman seledri.

Seledri merupakan salah satu jenis sayuran yang sudah lama dikenal di kalangan masyarakat. Seledri ini sendiri dimanfaatkan sebagai sayuran penyegar masakan atau bumbu karena seledri mengandung dan memiliki aroma yang khas untuk menyedapkan masakan. Selain digunakan sebagai bahan penyedap masakan, seledri juga memiliki manfaat yang sangat penting diantaranya dapat juga dimanfaatkan sebagai bahan obat-obatan dan kosmetik, karena dalam daunnya banyak mengandung saponin, flavonoida dan polifenol. Obat-obatan misalnya untuk mengobati tekanan darah tinggi, urine keruh dan masuk angin (Permadi dalam Erni, 2011).

Seiring dengan banyaknya manfaat dari seledri tersebut menjadikan seledri semakin banyak dikonsumsi masyarakat. Pemenuhan kebutuhan tersebut maka diperlukan usaha untuk peningkatan hasil tanaman seledri. Upaya yang dapat dilakukan untuk dapat meningkatkan hasil tanaman seledri yang baik yaitu dengan cara memilih media tanah dan pupuk yang baik. Jenis tanaman seledri daun umumnya ditanam di tanah yang subur (Soewito, 1999).

Berdasarkan kebutuhan media tumbuh seledri tersebut maka tanah yang akan digunakan yaitu tanah entisol. Tanah yang tergolong tanah entisol menurut Agustina (2007) "merupakan tanah baru yang bertekstur pasir atau pasir berlempung, sehingga mempunyai daya menahan air yang rendah". Kebutuhan media seledri yaitu memiliki kondisi yang lembab. Maka dari itu untuk dapat menjadi tempat tumbuh seledri yang baik perlu adanya penambahan seperti sekam padi agar tanah dapat mengikat air lebih lama sehingga kelembaban terjaga.

Berdasarkan permasalahan di atas, perlu dibuktikan ada atau tidaknya dampak negatif yang ditimbulkan dari penggunaan pupuk limbah cair nanas jangka panjang. Caranya membandingkan media tanam yang sudah terpapar limbah cair nanas satu kali dan terpapar dua kali dengan jenis tanah yang sama yaitu tanah entisol. Tanah entisol yang akan digunakan ini merupakan tanah yang sudah pernah digunakan sebagai media tanam tanaman sebelumnya. Maka dari itu akan digunakannya tanah entisol yang telah terpapar satu kali oleh pupuk limbah cair nanas dan sebagai pembandingnya yaitu tanah entisol yang terpapar pupuk limbah cair nanas sebanyak dua kali. Dimana hasil penelitian ini akan dijadikan sumber belajar.

Proses belajar mengajar dilakukan tidak selamanya guru mentransfer materi seluruhnya kepada siswa. Namun siswa juga dapat belajar 
secara mandiri. Artinya pembelajaran dapat dilakukan dengan cara berpusat kepada siswa dan guru hanya sebagai fasilitator. Siswa didorong agar mampu dan lebih baik dalam melakukan observasi (pengamatan), bertanya, menalar, mencoba, dan mengkomunikasikan obyek pembelajaran dengan baik. Hal itu tentunya siswa membutuhkan sumber belajar atau media pembelajaran yang mendukung. Salah satu media pembelajaran yang membantu siswa dapat memahami konsep pembelajaran dengan menggunakan Lembar Kegiatan Siswa (LKS). Menurut Depdiknas (dalam Puspitadewi, 2014) Lembar kegiatan siswa merupakan salah satu cara untuk memudahkan guru dalam melaksanakan proses pembelajaran dan memudahkan siswa untuk belajar secara mandiri, memahami, dan menjalankan suatu tugas.

Hasil penelitian ini diharapkan mampu menjadi alternatif baru sebagai sumber belajar untuk siswa SMA kelas XII pada materi pokok Pertumbuhan dan Perkembangan yang berupa Lembar Kegiatan Siswa (LKS). Adanya LKS ini siswa dapat dan mampu untuk menganalisis, berpikir kritis dan menemukan jawaban permasalahan mengenai materi Pertumbuhan dan Perkembangan. Oleh sebab itu, perlu diadakannya penelitian "Perbandingan Jenis Media Tanam Tanah Entisol yang Sudah Terpapar Satu Kali dan Dua Kali oleh Limbah Cair Nanas terhadap Pertumbuhan Seledri (Apium graveolens L.) sebagai Sumber Belajar Biologi”.

\section{METODE}

Penelitian ini menggunakan penelitian eksperimen, yaitu membandingkan pertumbuhan seledri yang ditanam di media tanam tanah entisol yang terpapar satu kali oleh pupuk LCN dan yang terpapar dua kali oleh pupuk LCN. Perlakuan dengan memberikan pupuk LCN sebanyak 200ml setiap 3 hari pada seledri yang ditanam di tanah entisol yang terpapar satu kali dan dua kali terpapar oleh LCN. Penelitian ini menggunakan Rancangan Acak Lengkap (RAL) karena penelitian ini dilakukan dengan kondisi yang seragam. "Rancangan Acak Lengkap (RAL) umumnya cocok digunakan untuk kondisi lingkungan, alat, bahan, dan media yang homogen" (Hanafiah 2010:34). Penelitian ini menggunakan 2 perlakuan, setiap perlakuan dilakukan sebanyak 16 kali pengulangan. Objek yang diamati pada penelitian ini yaitu pertumbuhan seledri (Apium graveolens L.).

\section{HASIL}

1. Rata-rata Tinggi Seledri $(\mathrm{cm})$

Hasil pengukuran tinggi seledri dapat dilihat pada diagram batang berikut ini adalah hasil tinggi seledri yang ditanam di tanah entisol yang terpapar satu kali oleh LCN dan terpapar dua kali oleh LCN selama 8 minngu dalam satuan centimeter. Pertambahan tinggi seledri dapat dilihat pada Gambar 1.

Berdasarkan diagram batang pada gambar 1 dapat dianalisis bahwa ratarata tinggi seledri dalam pengamatan selama 8 minggu selalu mengalami peningkatan baik pada seledri yang ditanam pada tanah entisol yang terpapar satu kali maupun yang terpapar dua kali oleh LCN. Tinggi seledri pada tanah entisol yang satu kali terpapar oleh LCN mengalami pertambahan tinggi antara $3-5 \mathrm{~cm}$ setiap minggunya. Hal serupa terjadi pada seledri yang ditanam di tanah entisol yang terpapar dua kali oleh LCN mengalami pertamabahan tinggi $3-4 \mathrm{~cm}$ setip minggunya. Rata-rata tinggi 
seledri pada minggu ke- 8 pada seledri yang ditaman di tanah entisol yang terpapar satu kali yaitu $22,27 \mathrm{~cm}$ lebih kecil dibandingkan dengan rata-rata tinggi seledri yang ditanam pada tanah entisol yang terpapar dua kali yaitu $23,32 \mathrm{~cm}$

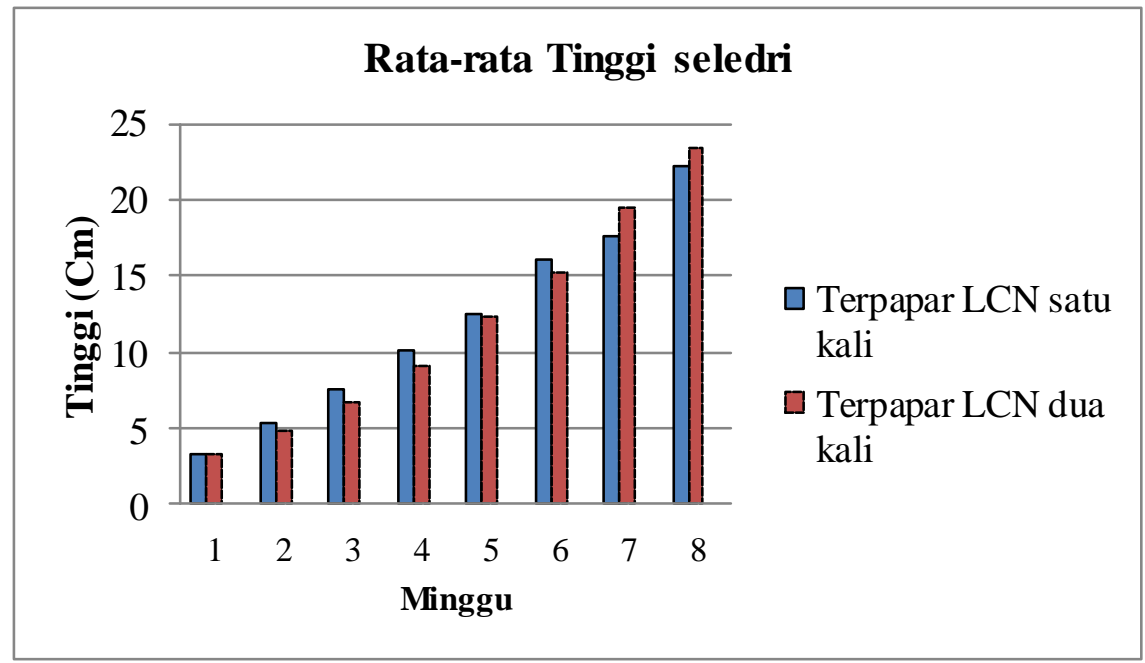

Gambar 1. Grafik Pertumbuhan Tinggi Seledri pada Media Tanah Entisol yang Satu Kali dan Dua Kali Terpapar Pupuk Limbah Cair Nanas (LCN).

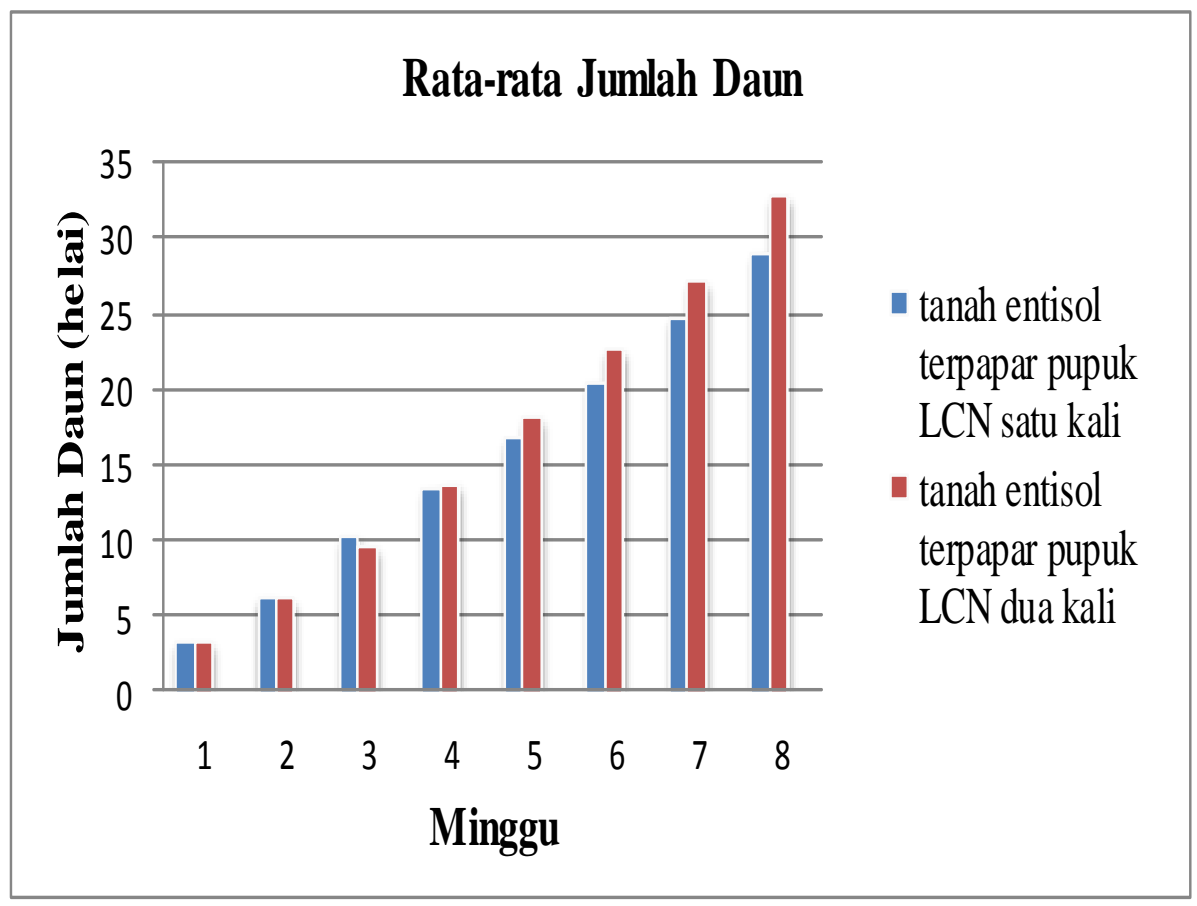

Gambar 2. Grafik Pertambahan Daun Seledri pada Media Tanah Entisol yang Satu Kali dan Dua Kali Terpapar Pupuk LCN 
2. Rata-rata Jumlah Daun Seledri (helai)

Hasil pengukuran daun seledri dapat dilihat pada diagram batang berikut ini adalah hasil rata-rata dalam dua perbandingan selama 8 minggu dengan satuan helai dari hasil pengamatan dapat dilihat pada Gambar 2.

Berdasarkan diagram batang pada gambar 2 dapat dianalisis bahwa ratarata jumlah daun seledri dalam pengamatan selama selalu mengalami peningkatan. Peningkatan terjadi baik pada perlakuan tanah entisol yang terpapar satu kali maupun terpapar dua kali oleh LCN. Pertambahan jumlah daun seledri rata-rata 3-4 helai pada setiap minggunya dan rata-rata jumlah daun pada minggu terakhir yaitu 29 helai. Rata-rata jumlah daun seledri tersebut lebih kecil jika dibandingkan dengan seledri yang ditanam pada tanah entisol yang terpapar dua kali oleh LCN bahwa rata-rata pertambahan daun setiap minggunya yaitu 3-5 helai daun. Rata-rata jumlah total daun seledri pada minggu ke- 8 yaitu 33 helai daun.

\section{Pembahasan}

\section{Tinggi Seledri (Apium graveolens} L.)

Hasil pengujian hipotesis tinggi seledri yang menggunakan perhitungan uji $\mathrm{t}$ didapatkan $-2,04<\mathrm{t}_{\text {hit }}=-0,09<$ 2,14 . Berdasarkan data yang diperoleh, artinya terlihat tidak ada perbedaan pertumbuhan tinggi seledri antara tanah entisol yang terpapar sekali dengan tanah entisol yang terpapar dua kali oleh pupuk LCN.

Pertumbuhan seledri pada media tanah entisol dipengaruhi juga oleh adanya unsur hara dari pupuk limbah cair nanas. Unsur yang dapat berpengaruh pada tinggi batang yaitu unsur N, P, K dan unsur-unsur lainnya. $\begin{array}{lrrr}\text { Unsur } \quad \mathrm{N} & \text { dapat } & \text { mendorong } \\ \text { pertumbuhan } & \text { batang } & \text { karena }\end{array}$ merangsang pertumbuhan secara keseluruhan (Munir, 2011). Selain itu unsur $\mathrm{P}$ dan $\mathrm{K}$ dari pupuk limbah cair nanas mempengaruhi pertambahan tinggi seledri. Bahwasannya unsur $\mathrm{P}$ berperan dalam memperbaiki pertumbuhan tanaman secara keseluruhan dan memperbaiki sistem perakaran tanaman. Sedangkan $\mathrm{K}$ merupakan unsur yang berperan untuk memacu pertumbuhan tinggi tanaman dan dapat ditunjang oleh unsur-unsur lainnya (Syahrudin, 2011).

Pupuk limbah cair nanas merupakan pupuk yang berbentuk cair dan berasal dari limbah nanas. Limbah cair nanas diolah menggunakan teknik bioremediasi. Bioremediasi sendiri merupakan penggunaan agen-agen biologik untuk menentralkan tanah dan air tercemar menjadi zat-zat yang tidak berbahaya bagi lingkungan (Waluyo, 2009). Proses bioremediasi limbah cair nanas melibatkan bakteri-bakteri, diantaranya Bacillus cereus, Acinetobacter baumanni, Bacillus subtilis dan Pseudomonas pseudomallei. Keempat bakteri tersebut berfungsi untuk menaikkan $\mathrm{pH}$ dan menjadikan $\mathrm{pH}$ tidak terlalu asam. Sehingga dapat diaplikasikan pada tanah dan apabila digunakan selanjutnya tidak akan merusak kondisi tanah.

\section{Jumlah Daun Seledri (Apium graveolens L.)}

Berdasarkan hasil perhitungan hipotesis menggunakan uji t, diperoleh bahwa $-2,04<-0,138<2,4$ maka Ho diterima. Sehingga dapat disimpulkan bahwa jumlah daun seledri pada media tanam tanah entisol yang terpapar pupuk limbah cair nanas satu kali maupun dua kali tidak terdapat perbedaan. 
Unsur hara yang terkandung dalam LCN akan diserap oleh akar dan daun. Daun dapat memanfaatkan sinar matahari yang lebih besar, sehingga laju fotosintesis akan meningkat. Menurut Saragih (2014) menyatakan jika laju foto sintesis meningkat maka fotosintat yang dihasilkan lebih banyak ditranslokasikan ke organ-organ pertumbuhan yakni titik tumbuh yang akan digunakan dalam pembentukan daun. Menurut Suhardi (dalam Saragih, 2014) dengan meningkatnya laju fotosintesis maka asimilat yang terbentuk juga akan semakin banyak, hal ini terlihat pada pertambahan jumlah daun.

Pembentukan daun oleh tanaman sangat dipengaruhi oleh ketersediaan unsur hara nitrogen dan fosfor pada tanah dan yang tersedia bagi tanaman. Hakim (dalam Marajahan, 2014) menyatakan kedua unsur fosfor dan nitrogen berperan dalam pembentukan sel-sel baru dan komponen utama penyusun senyawa organik dalam tanaman seperti asam amino, asam nukleat, klorofil, ADP dan ATP. Nitrogen yang cukup akan mendukung pertumbuhan tanaman menjadi lebih baik sehingga dapat meningkatkan jumlah daun. Sehingga pupuk LCN dapat menambah jumlah daun seledri.

Berdasarkan pada hasil analisis uji tanah dan pupuk, unsur P pada LCN sebanyak $0,01 \mathrm{mg} / 1$ namun setelah diberikan ketanah, $\mathrm{P}$ tersedianya menjadi 35,38ppm pada tanah yang sudah terpapar satu kali. Hal ini dikarenakan pupuk LCN membantu tanah mengikat $\mathrm{P}$ lebih banyak, sehingga tanaman mendapat unsur $\mathrm{P}$ bukan hanya dari LCN saja namun dari tanah. Unsur nitrogen merupakan unsur yang mengatur penyerapan hara salah satunya adalah fosfor. Jika tanaman kekurangan $\mathrm{N}$, maka tanaman akan tumbuh kerdil dan sistem perakarannya terbatas sehingga penyerapan fosfor kurang optimal (Santosa dalam Setyanti, 2013). Nitrogen adalah senyawa organik komplek yang menyusun protein, salah satu protein yaitu enzim. Aktifitas enzim dipengaruhi oleh $\mathrm{pH}$ sesuai dengan pendapat Lakitan (2008) bahwa aktifitas enzim akan menurun pada $\mathrm{pH}$ yang lebih tinggi atau lebih rendah. Enzim akan bekerja maksimum pada $\mathrm{pH}$ optimum yaitu berkisar antara $\mathrm{pH} 6$ sampai pH 8.

Berdasarkan analisis uji tanah yang belum terpapar dan yang sudah terpapar satu kali oleh LCN memiliki penurunan $\mathrm{pH}$ dari 7,07 menjadi 6,25. Penurunan $\mathrm{pH}$ terjadi tidak akan mempengaruhi proses pertumbuhan tanaman karena perubahan $\mathrm{pH}$ hanya terjadi pada satu kali pemaparan oleh LCN. pH tanah yang terpapar LCN berkali-kali akan tetap stabil, sehingga penggunaan LCN pada jangka panjang memiliki potensi yang baik untuk pertumbuhan tanaman.

Tanaman tidak menyerap seberapa banyak unsur hara yang tersedia namun tanaman menyerap unsur hara sebanyak yang dibutuhkan. Seberapa tinggi kandungan P-tersedia dalam tanah yang terpapar satu kali maupun dua kali oleh LCN tidak akan menyebabakan tanaman menjadi lebih tinggi dan jumlah daun lebih banyak, karena kandungan $\mathrm{P}$ yang tinggi terdapat pada $\mathrm{pH}$ yang rendah. Unsur $\mathrm{P}$ berguna bagi perakaran yang mengatur penyerapan unsur hara. Seberapa banyak unsur $\mathrm{P}$ yang diserap oleh tanaman jika kandungan $\mathrm{N}$ dan $\mathrm{K}$ pada tanah yang terpapar satu kali dan dua kali oleh LCN adalah sama maka pertumbuhan seledri tidak berbeda secara signifikan. Berdasarkan hal ini, maka asusmsi para petani yang menyatakan bahwa semua pupuk cair organik dapat merusak tanah dan 
menurunkan hasil tanaman, dapat dibantah karena berdasarkan penelitian ini pada penggunaan pupuk limbah cair nanas sama baiknya.

Berdasarkan hasil penelitian sumber belajar yang dibuat yaitu Lembar Kegiatan Siswa (LKS) materi Pertumbuhan dan Perkembangan SMA kelas XII, LKS telah dinyatakan valid serta layak untuk digunakan karena sudah melalui uji validasi dengan 1 dosen dan 2 guru SMA.

\section{KESIMPULAN DAN SARAN Kesimpulan}

Berdasarkan hasil penelitian yang telah dilakukan bahwa tidak ada perbedaan yang signifkan pertumbuhan seledri antara dua perlakuan tersebut dengan perhitungan tinggi seledri -2,04 $<\mathrm{t}_{\text {hit }}=-0,09<2,14$ dan jumlah daun $2,04<-0,138<2,4$. Berdasarkan hal itu dapat disimpulkan bahwa pupuk Limbah Cair Nanas (LCN) memiliki potensi yang sama baiknya pada tanah yang terpapar satu kali maupun yang terpapar dua kali oleh pupuk LCN. LKS Pertumbuhan dan Perkembangan memiliki kelayakan $85,3 \%$ dengan kriteria baik.

\section{Saran}

Agar menguji penggunaan pupuk LCN dalam jangka yang lebih panjang dan dapat diaplikasikan pada tanaman yang lainnya. Memanfaatkan hasil penelitian sebagai LKS di sekolah dan lengkapi tahap-tahap pengembangan petunjuk praktikum model 4D sampai tahap penyebaran (dessiminate).

\section{DAFTAR RUJUKAN}

Agustina, Chusnul. 2007. Pengaruh Pemberian Kompos terhadap Beberapa Sifat Fisik Entisol Serta Pertumbuhan Tanaman Jagung (Zea mays. L). Disertasi tidak diterbitkan. Malang:
Program Sarjana Universitas Brawidjaya.

Erni, Sri. 2011. Pengaruh Media Tumbuh dan Pupuk Organik Cair terhadap Pertumbuhan dan Hasil Tanaman Seledri. Jurnal pertanian. Vol 4 no 2. 7.

Hanafiah, Kemas Ali. 2010. Rancangan Percobaan Teori dan Aplikasi. Jakarta: Rajawali Pers.

Lakitan, Benyamin. 2010. Dasar-dasar Fisiologi Tumbuhan. Jakarta: Rajawali Pers.

Marajahan, Yudika, Islan, dan M. Amrul Khoiri. 2014. Aplikasi Pupuk NPK terhadap Pertumbuhan Kakao (Theobroma cacao 1.) yang Ditanam Diantara Kelapa Sawit. Jurnal Agroteknologi. Fakultas Pertanian Universitas Riau.

Munir, Rafli. 2011. Pengaruh Fine Compost Kotoran Ayam dengan Pupuk ZA terhadap Pertumbuhan dan Hasil Tanaman Seledri. Jurnal analisis teknologi pertanian. Vol 4.no 2.95. Hal 7.

Puspitadewi, Septiana. 2014. Profil LKS Materi Perubahan Lingkungan Berorientasi Kurikulum 2013 untuk Melatihkan Berpikir Kritis Siswa. Pendidikan Biologi, FMIPA, Universitas Negeri Surabaya. Berkala Ilmiah Pendidikan Biologi Vol.3 No.2 Mei 2014. Hal 17.

Saragih, Nelly Winda, Sampoerno, Islan. 2014. Pertumbuhan Bibit Karet (Hevea brasiliensis) Okulasi pada Media Campuran Subsoil dengan Pupuk Organik. Jom Faperta Vol 1 No 2. Jurusan Agroteknologi Fakultas Pertanian Universitas Riau. 
Setyanti,Y. H, Anwar, dan W. Slamet. 2013. Karakteristik Fotosintetik dan Serapan Fosfor Hijauan Alfalfa (Medicago sativa) pada Tinggi Pemotongan dan Pemupukan Nitrogen yang Berbeda. Animal Agriculture Journal, vol. 2. no. 1, 2013. Fakultas Peternakan dan Pertanian Universitas Diponegoro, Semarang.

Setyawati, Fifit Eka. 2014. Perbandingan Produksi Terung Antara Varietas Naga Ungu dan Bulat Hijau dengan Pemupukan Limbah Cair Nanas Sebagai Sumber Belajar Biologi. Skripsi tidak diterbitkan. Metro:
Universitas Muhammadiyah Metro.

Soewito. 1999. Bercocok Tanam Seledri. Jakarta: Titik Terang.

Sutanto, Agus. 2010. Bioremediasi Limbah Cair Nanas. Malang: UMM Pres.

Syahrudin. 2011. Respon Tanaman Seledri (Apium graveolens. L) terhadap Pemberian Beberapa Pupuk Daun pada Tiga Jenis Tanah. Jurnal Penelitian. Vol.12 nomor.1

Waluyo, Lud. 2009. Mikrobiologi Lingkungan. UMMPRESS. 